\title{
THE EFFECT OF SURGICAL TECHNIQUE ON DUODENOGASTRIC REFLUX AFTER CHOLECYSTECTOMY
}

\author{
Kolesistektomi Strasında Cerrahi Tekniğin Duodenogastrik Reflü Üzerine Etkisi
}

\author{
Yavuz PİRHAN ${ }^{* *}$ (D), Volkan TAŞOVA ${ }^{1}$
}

${ }^{I}$ Amasya University, Sabuncuoğlu Şerefeddin RT Hospital, Dept. of General Surgery, AMASYA, TÜRKIYE

\section{ABSTRACT}

Objective: It is stated in the literature that some patients have dyspeptic complaints after months from cholecystectomy. The reason for this situation has not been established. It is more often attributed to the bile leakage from the duodenum to the stomach. Therefore, in our study we investigated whether the surgical technique applied during cholecystectomy caused postoperative duodenogastric reflux. In this study, it was aimed to investigate the effects of Calot's triangle dissection type (high dissection, low dissection) on post-operative duodenogastric reflux due to Oddi's sphincter dysfunction during laparoscopic cholecystectomy.

Material and Methods: In the study, laparoscopic cholecystectomy was performed in two groups. One day before cholecystectomy, all patients underwent gastroscopy. During cholecystectomy, dissection of gallbladder was carried out close to the gallbladder in the first group (high dissection), while dissection was carried out close to ductus choledochus in the second group (low dissection). Two months after the operation, all patients were called back and gastroscopy was performed. Whether there was bile reflux from pylorus to the stomach was checked.

Results: Of the patients, $78.3 \%$ were female and $21.7 \%$ were male. The average age was 51.5 years (min-max: 25-76 years). Most of the patients (n:19, 31.7\%) were in the 4th decade. Post-operative bile reflux was detected in 25 (41.7\%) of all patients. Duodenogastric reflux was detected in 6 patients in group 1 and 19 patients in group 2 . While there was a statistically significant relationship between the occurrence of postoperative reflux and dissection type, age, ASA score and presence of diabetes, no relationship was found with gender.

Conclusion: If less duodenogastric reflux is desired after cholestectomy, we recommend dissection rather close to the gallbladder during cholecystectomy.
Amaç: Kolesistektomiden aylar sonra bazı hastalarda dispeptik şikayetlerin olduğu literatürde belirtilmektedir. Bu durumun sebebi tam olarak ortaya konamamıştır. Daha çok duodenumdan mideye doğru olan safra kaçağına bağlanmaktadır. $\mathrm{Bu}$ nedenle çalışmamızda kolesistektomi sırasında uygulanan ameliyat tekniğinin ameliyat sonrası duodenogastrik reflüye sebep olup olmadığını araştırdık. Bu çalışmada laparaskopik kolesistektomi sırasında Calot üçgeni diseksiyon tipinin (yüksek diseksiyon, alçak diseksiyon) ameliyat sonras1 duodenogastrik reflüye sebep olan Oddi sfinkteri yetmezliğine etkilerinin araştırılması amaçlanmıştır.

Gereç ve Yöntemler: Çalışmaya safra kesesi taşı tanısıyla laparoskopik kolesistektomi planlanmış 60 hasta alındı. Çalışma, her grupta 30 hasta olmak üzere iki grup olarak planland. Gruplardaki denekler randomize olarak belirlendi. American Society of Anesthesiologists (ASA) skoru 1-2 ve ameliyat öncesi gastroskopi ile duodenogastrik safra reflüsü saptanmayan hastalar çalışmaya dahil edildi. Birinci gruba alınan hastalara kolesistektomi sırasında safra kesesine yakın diseksiyon (yüksek diseksiyon), ikinci gruba alınan hastalar da ise koledoğa yakın diseksiyon (alçak diseksiyon) yapılarak kolesistektomi uyguland. Hastalar ameliyattan iki ay sonra tekrar çağrılıp gastroskopi yapıldı. Pilordan mideye safra reflüsü olup olmamasına bakıldı.

Bulgular: Hastaların \%78.3'ü kadın ve \%21.7'si erkekti. Yaş ortalamaları (minimum- maksimum) 51.5 yıl (25-76 y1l) idi. En çok 4. dekatta \%31.7 (n:19) hasta mevcuttu. Tüm hastaların 25 'inde (\%41.7) ameliyat sonrası safra reflüsü tespit edildi. 1. grupta 6 hastada, 2. grupta 19 hastada duodenogastrik reflü saptandı. Ameliyat sonrası reflü oluşması ile yapılan diseksiyon tipi, yaş, ASA skoru ve diyabet varlığ arasındaki istatiksel olarak anlamlı ilişki bulunmuşken, cinsiyet ile ilişki tespit edilememiştir.

Sonuç: Kolestektomi sonrası daha az duodenogastrik reflü gelişmesi isteniyorsa kolesistektomi sırasında safra kesesine oldukça yakın diseksiyon yapılmasını önermekteyiz.

Keywords: Bile reflux, duodenogastric reflux, cholecystectomy kolesistektomi 


\section{INTRODUCTION}

Although primary duodenogastric reflux (DGR) is rarely seen, it is one of the common diseases that occur after gastric or hepatobiliary surgery and adversely affects the patient's quality of life (1). Most of the studies are about DGR after gastric surgery, while studies concerning DGR after gall bladder surgery are not encountered frequently (2). In a study by Mercan et al. DGR was reported as high as $78 \%$ after cholecystectomy (3). In the literature review, reflux was detected after cholecystectomy, but it was not investigated whether this reflux was due to surgical technique. In our study, we investigated whether the Calot triangle dissection type (high dissection, low dissection) performed during cholecystectomy causes postoperative DGR.

\section{MATERIALS AND METHODS}

The research was started after the permission obtained from local ethics committee (Ondokuz May1s University Ethics Committe of Clinical Research, date: 17.01.2019; issue number: 2019/43). The study was performed on 60 patients who underwent laparoscopic cholecystectomy with the diagnosis of gallstones without any discrimination between men and women. The study was planned as two groups with 30 patients in each group. Patients in the groups were randomized. One day before cholecystectomy, patients underwent gastroscopy and the American Anesthesiologists Association (ASA) 1-2 score patients without bile reflux from pylorus to stomach were included in the study. After the patients were prepared for cholecystectomy with routine general anesthesia process, they were operated under general anesthesia. In Group 1, cholecystectomy was completed by performing dissection close to the gall bladder defined as high dissection during cholecystectomy (Figure 1). In Group 2, cholecystectomy was performed by performing dissection close to ductus choledochus defined as low dissection during cholecystectomy
(Figure 2). The patients were discharged one day after surgery without any morbidity and mortality. Patients were called two months after surgery and gastroscopy was performed again to check whether there was bile reflux from pylorus to stomach.

Operation technique:

Laparoscopic cholecystectomy was performed using classical 4 trocar technique as standard in all cases. Pneumoperitoneum with $12 \mathrm{mmHg}$ pressure was created with $\mathrm{CO}_{2}$ insufflation via a $10 \mathrm{~mm}$ belly hole trocar inserted using the open Hasson technique. The time from the insertion of the first trocar to the suture of the skin incision of the last trocar was recorded as the total operation time. With the initiation of cholecystoduodenal region dissection, the time elapsed until the dissection of the Calot triangle was completed and the clipping of the cystic artery and canal was recorded as the dissection time of the Calot triangle.

\section{Statistical Method}

Study data were evaluated with SPSS (Statistical Package for the Social Sciences) version 16.0 package program. Here, it was seen that the data did not show normal distribution since the "sig." values of the "Shapiro-Wilk" test were less than 0.05. One-Way ANOVA, Pearson Chi-Square tests were used as there were more than one group in the study. $\mathrm{P}$ values less than 0.05 were considered statistically significant. In the power analysis performed with the $G$ power program, a sample size of 30 subjects in each group, an average of 1.56 unit difference between groups, 0.8 unit standard deviation, $95 \%$ confidence interval and at least $95 \%$ test power were calculated (1).

\section{RESULTS}

Of the patients, $78.3 \%$ were female and $21.7 \%$ were male. The average age was 51.5 years (25-76 years). There were at least 19 patients $(31.7 \%)$ in the 4 th decade. Of the patients operated, $46.7 \%$ had ASA 1 risk and 53.3\% had ASA 2 risk. Diabetic patients 
constituted $25 \%$ of the patients. Postoperative reflux was detected in $25(41.7 \%)$ of all patients (Table 1).

Table 1: Data of all patients

\begin{tabular}{lcc}
\hline & n & \% \\
\hline Age & 3 & 5 \\
$20-30$ & 7 & 11.7 \\
$30-40$ & 19 & 31.7 \\
$40-50$ & 17 & 28.3 \\
$50-60$ & 11 & 18.3 \\
$60-70$ & 3 & 5 \\
$70-80$ & & \\
\hline ASA score & 28 & 46.7 \\
ASA 1 & 32 & 53.3 \\
ASA 2 & & \\
\hline Diabetes & 15 & 25 \\
Present & 45 & 75 \\
Not present & & \\
Sex & 47 & 78.3 \\
Female & 13 & 21.7 \\
Male & & \\
\hline Postoperative & & \\
duodenogastric reflux & 25 & 41.7 \\
Present & 35 & 58.3 \\
Not present & & \\
\hline
\end{tabular}

Table 2: Data of patients undergoing type 1 dissection

\begin{tabular}{lcc}
\hline Type 1 dissection & n & \% \\
\hline Age & 2 & 6.7 \\
$20-30$ & 2 & 6.7 \\
$30-40$ & 10 & 33.3 \\
$40-50$ & 8 & 26.7 \\
$50-60$ & 6 & 20 \\
$60-70$ & 2 & 6.7 \\
$70-80$ & & \\
\hline ASA score & 14 & 46.7 \\
ASA 1 & 16 & 53.3 \\
$\quad$ ASA 2 & & \\
\hline Diabetes & 7 & 23.3 \\
Present & 23 & 76.7 \\
Not present & & \\
\hline Sex & 21 & 70 \\
Female & 9 & 30 \\
Male & & \\
Postoperative & & \\
duodenogastric reflux & 6 & 20 \\
Present & 24 & 80 \\
Not present & & \\
\hline
\end{tabular}

Table 3: Data of patients undergoing type 2 dissection

\begin{tabular}{lcc}
\hline Type 2 dissection & $\mathrm{n}$ & $\%$ \\
\hline Age & 1 & 3.3 \\
$20-30$ & 5 & 16.7 \\
$30-40$ & 9 & 30 \\
$40-50$ & 9 & 30 \\
$50-60$ & 5 & 16.7 \\
$60-70$ & 1 & 3.3 \\
$70-80$ & 14 & 46.7 \\
\hline ASA Score & 16 & 53.3 \\
ASA 1 & & \\
ASA 2 & 8 & 26.7 \\
\hline Diabetes & 19 & 73.3 \\
Present & 22 & \\
Not present & & 86.7 \\
\hline Sex & 26 & 13.3 \\
Female & 4 & \\
Male & & \\
\hline Postoperative & & \\
duodenogastric reflux & & \\
Nresent & & \\
\hline
\end{tabular}

Reflux was detected in $42.1 \%$ (n: 8) of diabetic patients who were operated with ASA 2 risk (Table 3). While the type of dissection, age, ASA score and the effect of diabetes were found to be statistically significant in the occurrence of postoperative reflux $(\mathrm{p}<0.05)$, statistical significance of gender was not found in postoperative reflux $(\mathrm{p}=.79)$ (Table 4).

$53.3 \%$ of the patients who underwent type 1 dissection were operated with ASA 2 risk and $23.3 \%$ of these patients were diabetic. In addition, reflux was seen in six patients who underwent type 1 dissection, while one patient who was operated with ASA 1, five patients who were operated with ASA 2, and three patients from diabetic patients. Reflux was detected in $50 \%$ (n: 3 ) of diabetic patients who were operated with ASA 2 risk (Table 2). $53.3 \%$ of the patients who underwent type 2 dissection were operated with ASA 2 
risk and $26.7 \%$ of the patients were diabetic. In addition, reflux was seen in nineteen patients, five patients from those who were operated with ASA 1, fourteen patients from those who were operated with ASA 2, and eight patients from diabetics in patients undergoing type 2 dissection.

Table 4: Statistical comparison of groups

\begin{tabular}{|c|c|c|c|c|c|c|}
\hline One-Way ANOVA & & Sum of Squares & df & Mean Square & $\mathbf{F}$ & Sig. \\
\hline & Between groups & 2.897 & 1 & 2.897 & 13.884 & .01 \\
\hline \multirow[t]{3}{*}{ Type of dissection } & Within groups & 12.103 & 58 & .209 & & \\
\hline & Total & 15.000 & 59 & & & \\
\hline & Between groups & .012 & 1 & .012 & .068 & .79 \\
\hline \multirow[t]{3}{*}{ Sex } & Within groups & 10.171 & 58 & .175 & & \\
\hline & Total & 10.183 & 59 & & & \\
\hline & Between groups & 14.252 & 1 & 14.252 & 11.428 & .01 \\
\hline \multirow[t]{3}{*}{ Age } & Within groups & 72.331 & 58 & 1.247 & & \\
\hline & Total & 86.583 & 59 & & & \\
\hline & Between groups & 2.202 & 1 & 2.202 & 10.031 & .02 \\
\hline \multirow[t]{3}{*}{ ASA score } & Within groups & 12.731 & 58 & .220 & & \\
\hline & Total & 14.933 & 59 & & & \\
\hline & Between groups & 1.547 & 1 & 1.547 & 9.248 & .04 \\
\hline \multirow[t]{2}{*}{ Diabetes } & Within groups & 9.703 & 58 & .167 & & \\
\hline & Total & 11.250 & 59 & & & \\
\hline
\end{tabular}

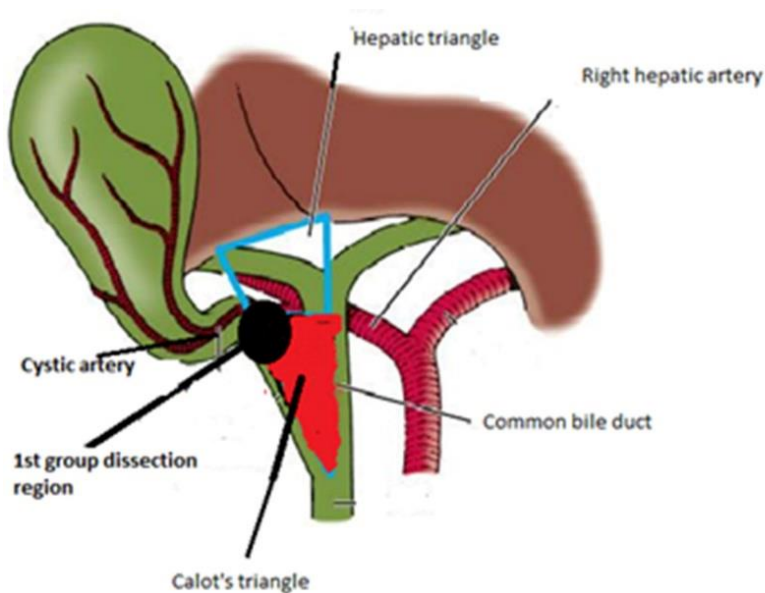

Figure 1: Area where type 1 dissection is applied

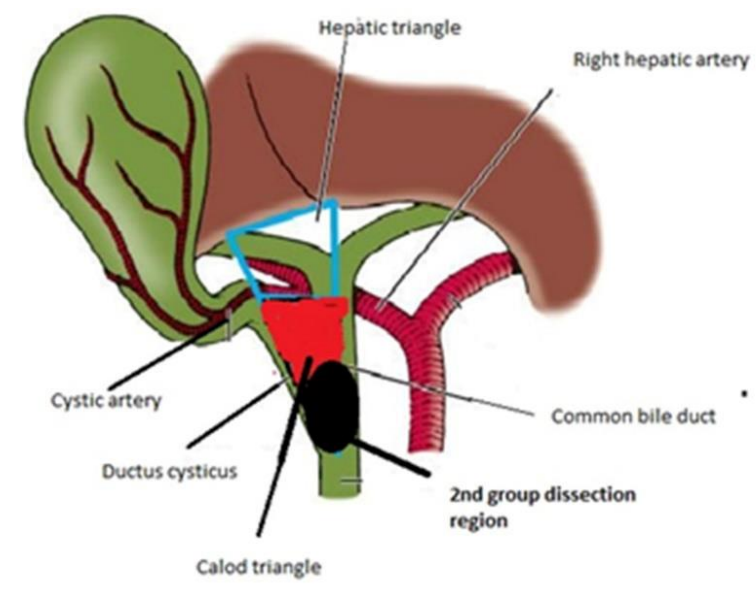

Figure 2: Area where type 2 dissection is applied 


\section{DISCUSSION}

Cholelithiasis is one of the most common problems affecting the digestive system. Although it depends on factors such as age, gender and ethnicity, 10-15\% of the adult population has gallstones. Therefore, cholecystectomy is the second most common general surgical procedure (4). Most of the symptoms resolve after cholecystectomy surgery. However, 15-20\% of patients present with new gastrointestinal symptoms or their preoperative complaints continue (5). Loss of the reservoir function of the gallbladder after cholecystectomy causes disruption of the cyclic pattern of excretion of bile, loss of neurohumoral responses causes motility changes in the upper gastrointestinal tract and increased DGR. Therefore, the return of the duodenal contents to the stomach induces permanent symptoms, such as epigastric pain, nausea and vomiting, by inducing gastric mucosal damage (6). Pathological DGR is seen in $51-89 \%$ of patients after cholecystectomy (7). In our study, DGR was seen in 25 of 60 patients. DGR after cholecystectomy is generally seen in women over 40 years of age (8). In our study, more DGRs were encountered in the 4th and 5th decades. Most of the patients were women. In other studies, it was shown that co-morbid disease was a factor in the occurrence of DGR, while in this study, we found that the rate of DGR increased with the increase in the risk score of diabetes and ASA. In our study, we thought whether surgical technique would cause DGR increase after gallbladder operations. When looking at the gallbladder and biliary tract anatomy, the gallbladder is connected to the main biliary tract with the bile duct, then it is connected to the duodenum with Oddi's sphincter distally, taking the name of common bile duct. In addition, the vascular and neural network that innervates and nourishes the bile duct, common bile duct and Oddi's sphincter is located here (9). Here, we thought that Oddi's sphincter, which drains bile to control the duodenum during cholecystectomy, would somehow cause DGR to occur due to impaired normal innervation and function. When we look at the literature, we did not come across a study similar to our study. There are studies mostly concerning the development of DGR after other surgeries (10). In the principle of safe cholecystectomy, it is preferred to stay away from common bile duct as much as possible (11). However, during safe cholecystectomy in long cystic duct cases, the cystic duct cannot be completely removed and a reservoir duct remains. However, in anatomically difficult cases, it is recommended to work away from the common bile duct (12). In our opinion, the vascular and neural network that damages and innervates the Oddi's sphincter is damaged during cholecystectomy. Therefore, we supported the hypothesis that if we work far from this vascular and neural network, the Oddi's sphincter deficiency will be so low. The findings of the study clearly show that DGR is significantly lower in the high dissection group than in the low dissection group. However, the presence of diabetes mellitus and chronic disease in patients also plays a role as a predisposing factor for DGR.

As a result, If DGR is desired to be seen less after cholecystectomy we recommend dissection as close to the gallbladder and as far as possible from common bile duct when performing cholecystectomy.

All authors meet the ICMJE authorship criteria

Conflict of Interest: The authors state that there are no conflicts of interest.

Support and Acknowledgements: The authors thank Mr. Ali Duran for excellent language assistance and the service nurses who helped us during patient follow-up. There are no financial supports.

Researchers' Contribution Rate Statement: YP and VT conceived and designed research. YP and VT conducted surcical. VT conducted gastroscopy. YP analyzed data. YP wrote the manuscript.

Ethical Committee Approval: Ondokuz May1s University Ethics Committe of Clinical Research, date: 17.01.2019; issue number: 2019/43. 


\section{REFERENCES}

1. McCabe ME, Dilly CK. New causes for the old problem of bile reflux gastritis. Clinical Gastroenterology and Hepatology. 2018;16(9):1389-92.

2. Madura JA. Primary bile reflux gastritis: diagnosis and surgical treatment. American Journal Surgery. 2003;186(3):269-73.

3. Mercan E, Duman U, Tihan D, Dilektasli E, Senol K. Cholecystectomy and duodenogastric reflux: interacting effects over the gastric mucosa. SpringerPlus. 2016;5(1):1-5.

4. Schaefer M, Krähenbühl L, Farhadi J, Büchler M. Cholelithiasis--laparoscopy or laparotomy? Therapeutische Umschau Revue Therapeutique. 1998;55(2):110-5.

5. Manifold D, Anggiansah A, Owen W. Effect of cholecystectomy on gastroesophageal and duodenogastric reflux. The American journal of gastroenterology. 2000;95(10):2746-50.

6. Latenstein CSS, Wennmacker SZ, de Jong JJ, van Laarhoven CJHM, Drenth JPH, de Reuver PR. Etiologies of long-term Postcholecystectomy symptoms: a systematic review. Gastroenterology research and practice. 2019;14;2019:4278373.

7. Chen H, Li X, Ge Z, Gao Y, Chen X, Cui Y. Rabeprazole combined with hydrotalcite is effective for patients with bile reflux gastritis after cholecystectomy. Canadian Journal of Gastroenterology and Hepatology. 2010;24(3):197201.

8. Emre Ş, Topuzlu Tekant G, Şenyüz OF. Laparoskopik kolesistektomi. Çocuk Cerrahisi Dergisi. 2016;30(Supp: 3):197-202.

9. Brunicardi FC, Anderson DK, Billiar TR, Dunn DL, Hunter JG, Matthews JH, Pollock RE. Schwartz's principles of surgery. 10th ed. New York. McGraw-Hill, 2015.

10. Sleisenger MH, Feldman M, Friedman LS, Brandt LJ. Sleisenger and Fordtran's Gastrointestinal and Liver Disease: Pathophysiology, Diagnosis,
Management. 9th ed. Philadelphia.

Saunders/Elsevier, 2010.

11. Buddingh $\mathrm{K}$, Morks A, ten Cate Hoedemaker H, Blaauw C, Van Dam G, Ploeg R et al. Documenting correct assessment of biliary anatomy during laparoscopic cholecystectomy. Surgical endoscopy. 2012;26(1):79-85.

12. Bourgouin S, Mancini J, Monchal T, Calvary R, Bordes J, Balandraud P. How to predict difficult laparoscopic cholecystectomy? Proposal for a simple preoperative scoring system. American Journal Surgery. 2016;212(5):873-81. 